\title{
The Effects of Genre-based Instruction on ESP Learners' Reading Comprehension
}

\author{
Bahador Sadeghi (Corresponding Author) \\ English Department, Islamic Azad University, Takestan Branch, Takestan, Iran \\ Mohammad Taghi Hassani \\ English Department, Islamic Azad University, Takestan Branch, Takestan, Iran \\ Mohammad R. Hemmati \\ English Department, Islamic Azad University, Takestan Branch, Takestan, Iran
}

\begin{abstract}
Despite the important role the genre-based instruction as a novice approach to teaching at tertiary level, little research has been done on its application in ESP learners' reading comprehension. Furthermore, the actual implementation of this approach and its outcomes on enhancing learners' reading comprehension have not yet been fully explored, this study aimed to investigate the effects of genre-based instruction on ESP learners' reading comprehension. The participants of the study included 116 junior and senior B.S students (both males and females) at Islamic Azad University of Kurdistan, majoring in biology. Participants were randomly assigned into 2 groups of control and experimental. The instructors taught the experimental group (genre-group) based on the genre and the control group (non-genre-group) based on the traditional method of teaching ESP, prevailing in Iranian universities. To meet the aim of the study, the instructors administered one 30-item proficiency test of English and two 30-item standard tests of English reading comprehension to the participants. The results of the reading comprehension test, analyzed through a t-test and independent samples test suggested teaching based on genre had a significant role in enhancing ESP learners' reading comprehension ability and the descriptive and inferential statistics showed learners improved significantly in reading comprehension compared with that of non-genre-group.
\end{abstract}

Index Terms - genre, genre analysis, genre move, genre-based instruction, esp, reading comprehension

\section{INTRODUCTION}

The term genre was first introduced in the area of English as Specific Purpose (ESP) and has been defined and discussed from different viewpoints. According to Hyland (2007) "genre refers to abstract, socially recognized ways of using language" (p. 149).Chandler (1997) states the term genre is generally used in rhetoric, literary theory, media theory, and more recently linguistics, to refer a distinctive type of text. According to Richards and Schmidt (2002), "agenre can be defined as: a type of discourse that occurs in a particular setting, that has distinctive and recognizable patterns and norms of organization and structure, and that has particular and distinctive communicative functions" (p. 224). Since the publication of Swales' "Genre Analysis" in 1990, more than two decades ago an increasing attention has been given to the concept of genre and its application in language teaching and learning. This has led to two prominent movements in the teaching and learning of languages, namely, English for Specific Purposes (ESP) and Systemic Functional Linguistics (SFL).According to Hyon (2001) previous studies carried out in ESP domain have generally reported positive effects of genre-based teaching for non-native English speakers; however, some have reported limitations. Johns (1997), for instance, puts forward the advantages of using what she calls a "socioliterate approach" to teaching reading and writing in developmental university composition of language minority students.

In the area of genre and second language reading instruction, according to Carrell (1985), schema research, as well has demonstrated positive outcomes of teaching genre structure on reading recall and/or comprehension. Furthermore, Hyon(2001) found that students who were interviewed immediately after an EAP genre-based reading course reported paying greater attention to rhetorical features in texts than before the course, as well as improved reading confidence and speed. Flowerdew (as cited in Chen, 2008) states there are two major approaches to genre theory: a text-based approach and a situation-oriented approach. In the case of text-based approach there is a focus on analyzing and describing textual patterns of different genres. In a situation-oriented approach of genre theory, according to Chen (2008), the focus is on the dynamic and evolving nature of genre and seeks a description of the situational contexts in which writing takes place. In another genre categorization according to Derewianka (1990) there are six main genres concerning their primary social purposes:

(1)Narratives which tell a story and usually aim to entertain; (2) Recount which tell what happened; (3) Information Reports which provide factual information; (4) Instruction which tell the listeners or readers what to do;(5)Explanation which explain why or how something happens;(6) Expository texts which present or argue a viewpoint. Also various 
texts, according to Cometorich (2009),are classified into different genres based on the following characteristics: 1) The purpose of communication or social function which refers to the reasons why we speak or write or create the text,2) The organization structure of the text or generic structure which implies the text organization or text arrangement, and 3) Language features or lexical grammar which are such things as the grammar, vocabulary and connectors that we use.

According to Torok and Waugh (2006) "Freedman and Medway (1994), two well-known American scholars in the New Rhetoric school, give their view that context determines the shape of genre: situation, motive, substance, and form play a part in defining the genre, but the whole is greater than and different from the sum of these parts" (p. 520).As a new approach in language teaching, there are still some vague issues in genre-based language teaching concerning learners' reading skill. For instance, it is not clearly realized to what extent the covered genres in class affects learners' comprehension of the reading materials; therefore, it is desirable to assess learners' comprehension of texts through using pretest and posttest to find out whether they have made any progress. This study attempts to investigate the effects of GBI on ESP learners' reading comprehension.

\section{Genre-based Instruction (GBI)}

Although there has been considerable research on Genre-Based Instruction (GBI) since 1985, little has dealt with the effects of GBI on learners' reading comprehension. When encountering a new academic genre, a student is faced with the task of learning how to read the texts produced within it. Most researches on GBI have been carried out in writing skill and the description of the textual forms and linguistic features of specific genres. However, the current study intends to show it is useful to help learners become aware of the textual regularities of a genre, instructors need to go beyond just analyzing the textual features of the text for learners and they have to assess their learners' comprehension of the texts.GBI has been also referred to as teaching language based on results of genre analysis. According to Swales (as cited in Osman, 2004) "genre analysis is the study of how language is used within a particular setting and according to Bhatia (as cited in Osman, 2004) it is concerned with the form of language use in relation to mean" (p. 2).Based on the model proposed by Cope and Kalantzis (as cited in Osman, 2004), there are four stages of GBI including modeling, guiding, practicing and finally independently writing the genre. In the literature on genre, there are three main approaches to genre theory: 1) The Australian Genre Approach, 2) The New Rhetoric Studies, and 3) English for Specific Purposes. Each of these approaches has its specific view regarding the way in which genres should be taught. For instance, according to Master (2005) the American New Rhetoric position is that genre specifications should not be taught explicitly. The Australian School of Systemic Functional Linguistics, on the other hand, believes that genre specifications should be explicitly taught. Master, further adds ESP practitioners are inclined to use the Australian notion of genre to all non-English-speaking students, including those in academic and professional contexts, leading to accusations in some quarters that the teaching of genre specifications suppresses creativity, and raising the issue of whether genre teaching is ultimately a scaffold or a straitjacket. Genre-based instruction mostly makes use of the theory of Systemic Functional Linguistics (SFL). Halliday (1985), the SF linguist, proposed the relationship between the use of language and the social environment. According to Christie (1999), in SF theory, language is referred to as being "systemic" in that it offers systems of choices in language, each significant for the realization of meaning; and language is referred to being "functional" because its organization represents the purposes for which any natural language came into being.

According to Nunan (1999) GBI approach has been confused with its more popular counterparts the "product approach" and the "process approach". The former involves imitating, copying, transforming models provided by the teacher and emphasizing the error free final product, and the latter focuses on the process of producing a piece of writing from the prewriting stage for the revising state to the final writing regardless of the time it takes. Genre-based instruction, according to Badger and White (2000), is actually an integration of the product approach and the process approach which results in a process-genre approach. According to Miller (1984) learning a genre is not just learning linguistic forms and conventions, but also it is learning how to participate in the actions of a community. This type of instruction is based on this concept that genres are specific to particular cultures and remind the instructors that their students may not share this knowledge with them and making them go beyond syntactic structures, vocabulary, and composing to incorporate into their teaching the ways language is used in specific contexts. According to Tuan( 2011) in this approach, any student who wants to be successful in communicating with a particular English-language discourse community needs to be able to produce texts which fulfill the expectations of their readers in regards to grammar, organization, and content.

\section{METHODOLOGY}

\section{A. Participants}

This study was carried out on tertiary level students studying for a B.S. in biology in Sanandaj Azad University. The research population included all the junior and senior students studying for a B.S. degree in biology at the time of the study. The participants were selected among 116 male and female junior and senior students. Through using a proficiency test, 60 homogeneous students were chosen in terms of their reading comprehension ability. These 60 students were randomly assigned to a control group of 30, and an experimental group of 30 .

\section{B. Instrumentation}


The two utilized instruments in this study are explained as follows:

\section{Proficiency Test}

In this study, to have a homogeneous group, the instructors administered a proficiency test of English developed by Cambridge Michigan ECCE. As the purpose was to match the participants in terms of their reading ability, just the reading section of the test was included. The test entailed three reading passages. It took about 35 minutes. The first passage, followed by 6 multiple-choice items; the second, 11 multiple-choice items, and the last had 13 items. The proficiency test was administered to choose the more homogeneous students out of the population and to put them randomly into experimental and control groups (See Appendix A).

\section{Pre-test and Post-test}

The instructors administered two standard tests of English reading comprehension adopted from Preliminary English Tests (PET) developed by Cambridge University. One of them was used as a pre-test and the other as a post-test. Only the reading section of these tests was used because the aim was to test the participants in terms of their reading ability. Both pre-test and post-test were divided into two sections: 1) General English and, 2) Specific English. The general English section included a reading comprehension passage followed by 5 multiple-choice items and 1 cloze-test with 10 multiple-choice items. The specific section contained two reading comprehension passages each followed by 5 multiple-choice items (See Appendices B \& C).

\section{E. Procedure}

To determine the reliability and validity of the instruments developed for the study, a pilot study aimed to clarify the procedures implemented for the study was conducted during the summer semester of 2012. Fifteen learners, having the same level of proficiency, were selected randomly from the target population of the study and were recruited to go through the same procedures of data collection for the present study. Clear understanding of the purposes of the study among the participants was observed and the amount of the allotted time for each test proved to be sufficient. The study was conducted at Biology Faculty of Sanandaj Islamic Azad University. The participants formed two reading classes that were held in two 90-minute sessions a week during one month. The researchers taught the control group through the traditional method which is prevalent in this university just like other universities in Iran, and the researchers taught the experimental group through genre-based instruction. A strong effort was made to treat both the experimental group and the control group the same, except for the difference in teaching method. All the data were collected within 2 months. Although two different methods of instruction were practiced, both groups were taught the same book, namely, English for the students of Biology 3, published by SAMT publications and written by Hossein Farhady (2006).

As already mentioned, the aim of the study was to examine how genre-based instruction improves ESP learners' reading comprehension. Therefore, genre-specific strategies were taught to the students. The two teaching procedures utilized are explained below:

\section{F. Traditional Method}

The traditional method taught by the researchers is primarily based on an analytic approach, which begins with words' definitions and translations then analyzes the words into different parts of speech to teach them. The ordinary process of teaching a lesson in such classes is that the instructor usually starts the lesson by explaining the meaning of the new words in Persian. Then, s/he asks a student to read some parts of the reading and helps them to translate those parts into Persian. After finishing the reading, the instructor explains the grammatical structures of the reading. Finally, students have to do the exercises after each reading and read their answers to the class accompanied by translating every sentence into Persian. After that, the instructor corrects students if they are wrong. Sometimes, the students do the exercises as homework for the next session.

\section{G. Genre-based Method}

Two common types of texts, which are used more in academic settings are expository and narrative texts. According to Weaver and Kintsch (as cited in Haria, 2010)narrative texts are written to entertain, but expository texts are written to communicate new information or knowledge.In other words, expository genres are designed to inform, report, and describe. They have a variety of structures and textual elements. They also make use of charts, maps, graphs, diagrams, photos, reading guides, etc. As the plethora of texts in ESP, especially in basic sciences such as biology fall in the category of expository genre, so the five common text structures or organizational structures of expository genre was explicitly explained to the learners. First of all, the instructors explained the expository genre to learners and introduced them its five patterns. Second, the instructors explained each of these patterns to learners in terms of their description, cue words, and graphic organizer. The explanations presented to the learners are outlined in the following table: 
TABLE 1

FIVE TEXT STRUCTURES OR ORGANIZATIONAL STRUCTURES OF EXPOSITORY GENRE

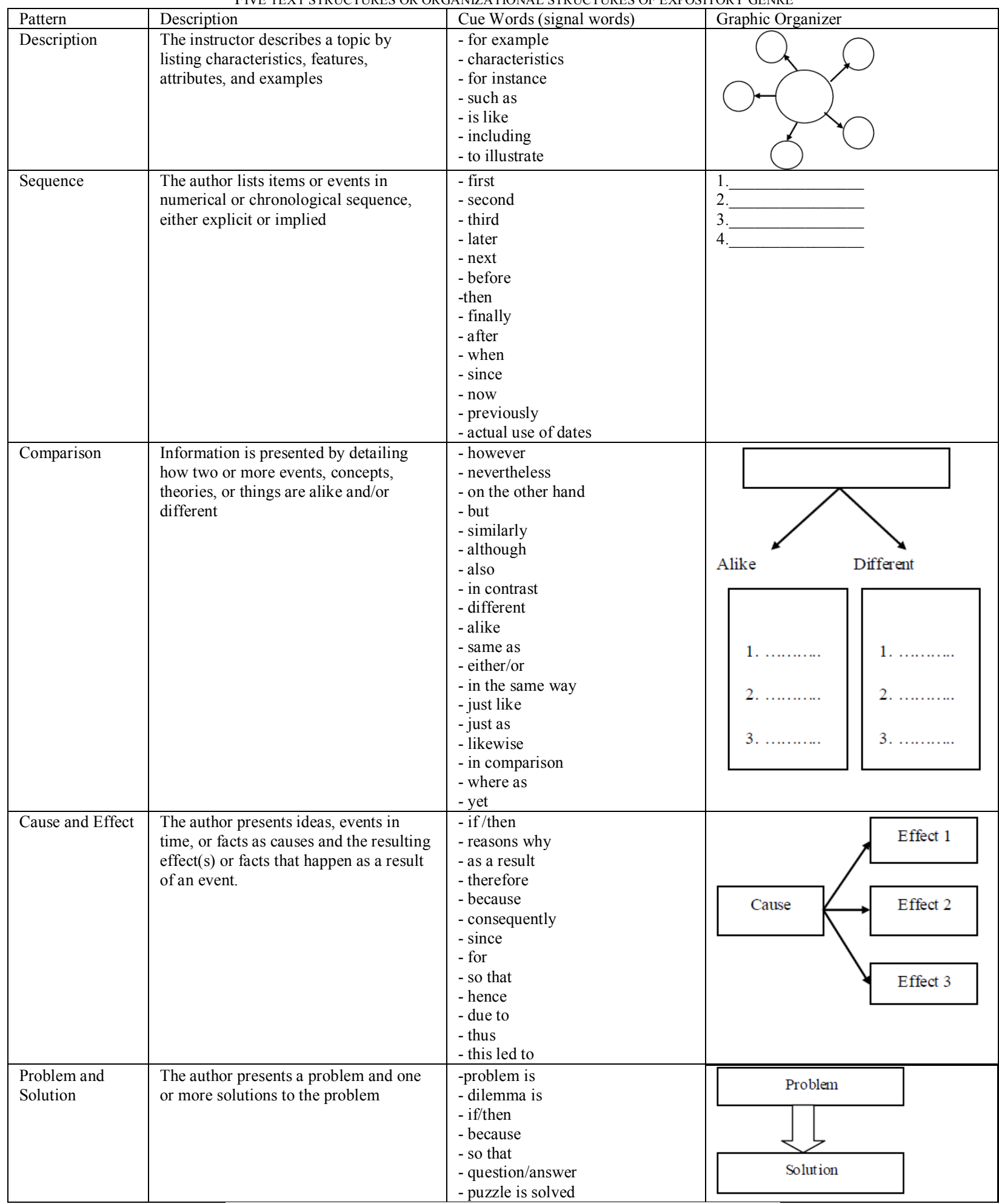

Extracted from: www.u-46.org/dbs/roadmap/ files/comprehension/3expostext.pdf

Following these explanations, one sample of each of these genres was given to the learners to work on in pairs or small groups. Learners' tasks were to identify each genre and analyze it in terms of its cue words and draw its graphic organizer.

In addition, a KWL comprehension technique which is used for enhancing reading comprehension of SLLS was taught and explained to learners. This technique aims to enable teachers to access the prior knowledge of students and to help students develop their own purposes for reading expository text. In acronym KWL, "K" stands for helping students recall what they "Know" about the subject, "W" Stands for helping students determine what they "Want" to learn, and "L" stands for helping students identify what they "Learn" as they read. (See Appendix D) 


\section{H. Design}

In the present study which has an experimental method, both groups of control and experimental took two standardized reading comprehension tests, one as a pre-test and the other as a post-test. The control group received the instruction through a traditional method and the experimental group received a genre-based instruction. The conducted treatments in this study are summarized in table 3.2 :

TABLE 2

SUMMARY OF THE TWO TREATMENTS

\begin{tabular}{|l|l|l|l|l|}
\hline Treatment 1 & Group 1 (Control) & Pre-test & - GBI & Post-test \\
\hline Treatment 2 & Group 2 (Experimental) & Pre-test & + GBI & Post-test \\
\hline
\end{tabular}

1) - GBI stands for teaching based on no Genre-Based Instruction or Traditional Method.

2 ) + GBI stands for teaching based on Genre-Based Instruction

\section{Data Analysis}

Following the administration of the pre-test and post-test, in order to test the research hypothesis and answer the research question, two independent sample tests for the pre-test and post-test were run to investigate the relationships between genre-based instruction as an independent variable and enhancing ESP learners' reading comprehension as a dependent variable.

In order to make sure that the participants were at the same level in terms of general language proficiency, the reading comprehension section of a version Cambridge Michigan ECCE was administered to all the participants $(n=116)$. The proficiency test consisted of thirty items each was given one point and no negative scores was considered for wrong answers. Table 3 shows the results.

TABLE 3

THE DESCRIPTIVE STATISTICS OF THE CAMBRIDGE MiCHIGAN ECCE PROFICIENCY TEST

\begin{tabular}{|l|l|l|l|l|l|}
\hline Total N & Minimum & Maximum & Mean & Std. Deviation & Valid N \\
\hline 116 & 20 & 29 & 24.3000 & 2.70780 & 60 \\
\hline
\end{tabular}

TABLE 4

THE STATISTICS FOR THE CENTRAL TENDENCIES OF PRE-TEST AND POST-TEST

\begin{tabular}{|ll|l|l|}
\hline Statistics & Pre-test & Post-test \\
\hline $\mathrm{N}$ & Variables & 60 & 60 \\
Mean & 0 & 17.9333 & 0 \\
Median & 17.5000 & 19.5333 \\
Std. Deviation & 4.86379 & 19.0000 \\
Variance & 23.656 & 4.28820 \\
Range & 18.00 & 18.389 \\
Minimum & 10.00 & 18.00 \\
Maximum & 28.00 & 10.00 \\
\hline
\end{tabular}

In Table 4, the statistics of pre-test and post-test are described in terms of the number of variables and missing which are 60 and 0 respectively. The mean of the pre-test is 17.93 and for the post-test is 19.53 . The median for the pre-test and post-test are 17.50 and 19.00. The standard deviation of pre-test is 4.86 and that of post-test is 4.28 . The pre-test variance and range are 23.65 and 18.00 and for the post-test these numbers are 18.38 and 18.00. The minimum and maximum of numbers in pre- and post-test are 10.00 and 28.00 respectively.

T-TEST TABLE 5

THE GROUP STATISTICS FOR THE PRE-TEST

\begin{tabular}{|ll|l|l|l|l|}
\hline & Groups & N & Mean & Std. Deviation & Std. Error Mean \\
\hline \multirow{2}{*}{ Pre-test scores } & Control Group & 30 & 17.8333 & 4.42628 & .80812 \\
& Experimental Group & 30 & 18.0333 & 5.34005 & .97495 \\
\hline
\end{tabular}

In Table 5, the control and experimental groups are compared in terms of the mean, which in control group is 17.83 while in the experimental group is 18.033; their standard deviation, which is 4.42 the control group and 5.34 for the experimental group, and the standard error mean of .80 for the control group and .97 for the other.

Based on the t-test for the independent samples test the researcher hypothesized that the language proficiency level of the control and experimental groups in pre-test scores seem to be different. 
TABLE 6

INDEPENDENT SAMPLES TEST FOR THE PRE-TEST INDEPENDENT SAMPLES TEST

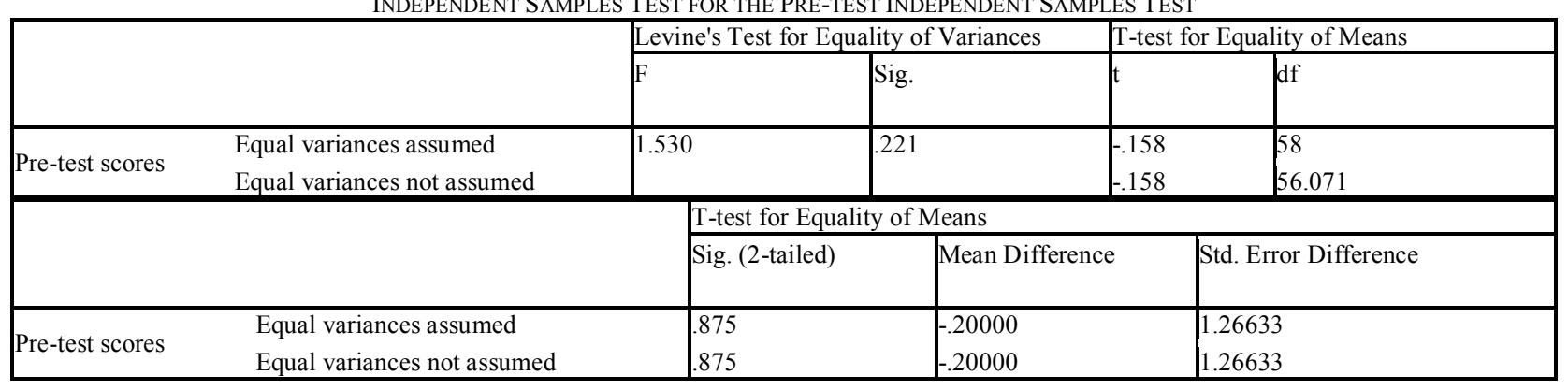

INDEPENDENT SAMPLES TEST

\begin{tabular}{|ll|l|l|}
\hline \multirow{4}{*}{} & & T-test for Equality of Means \\
\cline { 3 - 4 } & & $95 \%$ Confidence Interval of the Difference \\
\cline { 2 - 4 } & & Lower & Upper \\
\hline \multirow{2}{*}{ Pre-test scores } & Equal variances assumed & -2.73484 & 2.33484 \\
& Equal variances not assumed & -2.73670 & 2.33670 \\
\hline
\end{tabular}

According to the Table 6, which summarizes the t-test statistics on pre-test, the significance is .22 and it is more than the .05 ( $>$ >. 05), therefore the two variances are equal. Also based on the amount of Sig. In t-test Table (Table 6) which is .87 and it is more than .05 ( $p>.05)$, the assumed hypothesis, which states that the language proficiency level of the control and experimental groups in pre-test scores seem to be different, is rejected. The results of Levine's test show that there are no meaningful differences between the pre-test scores of both control and experimental groups and the two groups are nearly equal regarding their language proficiency level in pre-test scores. The rate of significant difference in control and experimental groups is only .20 which is regarded as a trivial difference and has no meaningful difference.

T-TEST TABLE 7

THE GROUP STATISTICS FOR THE POST-TEST GROUP STATISTICS

\begin{tabular}{|ll|l|l|l|l|}
\hline & Groups & N & Mean & Std. Deviation & Std. Error Mean \\
\hline \multirow{2}{*}{ Post-test scores } & Control Group & 30 & 18.2333 & 4.20741 & .76816 \\
& Experimental Group & 30 & 20.8333 & 4.02649 & .73513 \\
\hline
\end{tabular}

In Table 7, the control and experimental groups are compared in terms of the mean, which in control group is 18.23 while in the experimental group is 20.83 ; their standard deviation, which is 4.20 in the control group and 4.02 for the experimental group, and the standard error mean of .76 for the control group and .73 for the other. Based on the t-test for the independent samples test hypothesized that regarding the treatment or the two various teaching methods, the obtained scores of the post-test from the control and experimental groups seem to be different.

TABLE 8

INDEPENDENT SAMPLES TEST FOR THE POST-TEST INDEPENDENT SAMPLES TEST

\begin{tabular}{|ll|l|l|l|l|}
\hline \multirow{2}{*}{} & & Levine's Test for Equality of Variances & T-test for Equality of Means \\
\cline { 3 - 5 } & F & & Sig. & t & \\
\hline \multirow{2}{*}{ Post-test scores } & $\begin{array}{l}\text { Equal variances assumed } \\
\text { Equal variances not assumed }\end{array}$ & & .678 & -2.445 \\
& & -2.445 & 58 \\
\hline
\end{tabular}

INDEPENDENT SAMPLES TEST

\begin{tabular}{|c|c|c|c|c|}
\hline & & \multicolumn{3}{|c|}{ T-test for Equality of Means } \\
\hline & & Sig. (2-tailed) & Mean Difference & Std. Error Difference \\
\hline \multirow{2}{*}{ Post-test scores } & Equal variances assumed & .018 & -2.60000 & 1.06325 \\
\hline & Equal variances not assumed & .018 & -2.60000 & 1.06325 \\
\hline
\end{tabular}

INDEPENDENT SAMPLES TEST

\begin{tabular}{|ll|l|l|}
\hline \multirow{4}{*}{} & & T-test for Equality of Means \\
\cline { 3 - 4 } & & $95 \%$ Confidence Interval of the Difference \\
\cline { 2 - 4 } & & Lower & Upper \\
\hline \multirow{2}{*}{ Post-test scores } & Equal variances assumed & -4.72832 & -.47168 \\
& Equal variances not assumed & -4.72841 & -.47159 \\
\hline
\end{tabular}

According to the Table 8 which summarizes the t-test statistics in post-test the significance in Levine's Table is .67 and it is more than .05 ( $\mathrm{p}>$. 05), so the variances are equal. Based on the amount of significance in the t-test table which 
is .01 and it is less than the meaningful level of .05 $(\mathrm{p}<.05)$, the assumed hypothesis, which states regarding the treatment or teaching based on genre, the obtained scores of the post-test from the control and experimental groups seem to be different, is confirmed. In other words, it can be deducted the teaching method based on genre enhances ESP learners' reading comprehension since there is a meaningful difference between the obtained scores of the control and experimental groups in post-test. The experimental group which has been taught through the genre-based instruction has gained a higher mean in post-test than the control group, which has been taught through a traditional method.

\section{DISCUSSION}

The present study attempted to investigate the effects of genre-based instruction on ESP learners' reading comprehension. The finding of the present study supports some previous studies carried out in ESP domain and reported positive effects of genre-based teaching for non-native English speakers (Hyon, 2001; Henry \& Roseberry, 1998). John (as cited in Hyon, 2001), for instance, puts forward the advantages of using what she calls a " socioliterate approach" to teaching reading and writing in developmental university composition of language minority students. She notes that one writing task using this approach, a letter to the university president, was particularly successful.

Furthermore, Hyon (2001) found that students interviewed right after an EAP genre-based reading course reported paying more attention to rhetorical features in texts than before the course, as well as improved reading confidence and speed, this in turn, supports the finding of this study to some extent.

Contrary to the findings of the present study, some other studies in the literature report different results regarding the explicit teaching of genre features. For instance, according to Hyland (as cited in Ribeiro, 2008) "genre pedagogy, is also criticized for being static and decontextualized based on the claim that the teacher is not able to reproduce in class the culture and contexts by which texts are shaped" (p. 6).

Furthermore, according to Cope and Kalantzis (as cited in Ribeiro, 2008) "genre-based instruction teaches "language facts" analogous to the old authoritarian classrooms where students' achievements depend on how successfully the 'rules' can be applied"' (p. 5).

Based on the findings of this study, the explicit teaching of the expository genre and its five text structures helps ESP learners to enhance their reading comprehension.

The effectiveness of genre-based instruction of reading comprehension and the success of teaching reading comprehension through a genre-based approach may depend on many conditions including the learners' contexts, levels of proficiency, genre sensitivity, and many other individual and social differences.

The findings of this study also sensitize ESP instructors to the properties of the expository genres used in ESP reading comprehension classes majoring in biology. Researchers in favor of the genre-based instruction approach encourage teachers to learn more about the genre so that they can teach this knowledge to their students in order to enhance their students' awareness of different genres.

\section{CONCLUSION}

This study aimed to answer the question of the effects of genre-based instruction on Iranian ESP learners' reading comprehension.

With respect to the research question, the effects of genre-based instruction on ESP learners' reading comprehension was checked and the analysis of the related data resulted in significant findings and indicated there was a positive relationship between teaching based on genre and enhancing learners' reading comprehension.

Based on the results of the scores of the control and experimental groups in pre-test reading comprehension, it was revealed that there is no significant difference in the learners' reading comprehension. After the treatment both groups were taught based on two different methods of teaching, the results of descriptive statistics showed the experimental group performed better in post-test reading comprehension.

Therefore, it can be concluded that teaching ESP learners based on the principles of genre-based instruction has a significant effect on enhancing learners' reading comprehension.

\section{A. Pedagogical Implications}

The findings of this study may offer some pedagogical implications for instructors, material developers and syllabus designers.

One of the prominent implications for instructors is that they can teach related genres in their classes through teaching them explicitly and using pertinent techniques such as KWL to enhance ESP learners' reading comprehension instead of resorting to just translating from English to Persian. The obtained results from the present study also can help instructors to teach the reading comprehension-based textbooks designed for Iranian ESP learners through a more purposeful and contextualized setting along with more interaction with the instructor and the other learners.

The important implication for material developers and syllabus designers will be that the rigid format of current ESP textbooks which are dictated by the official center for materials in humanities, say, SAMT should be reviewed to provide the learners with texts not just being replete with technical terms without providing learners with opportunities 
to use these terms in realistic tasks and situations. Material developers should equip textbooks with more pictures, diagrams, and graphs which are in a great deal neglected in SAMT books.

Furthermore, genre-based approach can play an important role in designing syllabuses and developing materials based on the specific texts which learners are faced with more, in real situations and in higher levels. Material developers and syllabus designers should improve the quality of materials and textbooks with a close consideration of the characteristics of different genres regarding the learners' field of study.

\section{B. Suggestions for Further Research}

This study was an attempt to investigate the effects of genre-based instruction on Iranian ESP learners' reading comprehension. Regarding the findings of this study, the following areas are worthy of further investigation and are suggested as the starting point for further studies for those who are interested in conducting research in the area of genre-based instruction:

1. This study was carried out with both male and female participants; other studies can be conducted with male and female participants in separate groups to make the difference between the two genders clear.

2. This study was carried out by senior and junior university students at the intermediate level of proficiency. It is suggested that other researchers investigate the effects of genre-based instruction on ESP learners' reading comprehension at different proficiency levels.

3. In this study, among various genres, the expository genre, which is used more in ESP textbooks, was explained and taught to the learners. It is suggested that other types of genres and their effect on reading comprehension be investigated for further research.

4. The age of participants in this research was limited to the third and fourth-year university students. It is suggested to carry out the same study on students at different ages.

\section{Appendix A A Sample of CAmbridge Michigan ECCE Proficiency Test}

Name:

Date:

Cambridge Michigan ECCE (Reading)

Difficulty level: B2 / advanced

\section{Part (1) Read the text and then answer questions 1-6}

Everybody loves to play board games sometimes, but it is surprising to know how long this pastime has been in existence. Some of the earliest board games are over five thousand years old. The oldest is probably Senet, an Ancient Egyptian game which has been found in burials from before 3000BC. The game involves an element of luck, and so it was thought by the Ancient Egyptians that those who won the game were protected by the Gods. For this reason, games of Senet were often buried alongside the body in the grave, to be used on the dangerous journey to the afterlife. The game can also be seen on a number of paintings in tombs. The game board is set out as a grid of three by ten rows, and uses two sets of at least five pawns. The actual rules are unknown, although some historians have proposed rules which are used in the Senet sets available today.

The Royal Game of Ur, also known as the Game of Twenty Squares, is another ancient game which dates back to the First Dynasty of Ur, in 2600 BC Mesopotamia. It was played with two sets of seven markers, one black and one white, and three four-sided dice. Although the ancient rules are unknown, a stone tablet has been found which depicts a reliable record of how the game was played in 177-176 BC.

Both Senet and The Royal Game of Ur are probably predecessors to the game backgammon, which itself has a long history. The game of Nard, which existed in Iran in around 3000BC, used two sets of fifteen counters, four dice and same board as the one used in backgammon today, although the initial starting positions and rules are different. Similar games were played in Ancient Rome and India.

\section{APPENDIX B PRE-TEST}

Name:

Date:

Part A. General English

You are going to read a magazine article about an author.

For questions 1-8, choose the correct answer A, B, C, D. Mark your answers on the answer sheet. (There is only one possible answer.)

'A good book for children should simply be a good book in its own right.' These are the words of Mollie Hunter, a well-known author of books for youngsters. Born and bred near Edinburgh, Mollie has devoted her talents to writing primarily for young people. She strongly believes that there is always and should always be a wider audience for any good book whatever its main market. In Mollie's opinion it is essential to make full use of language and she enjoys telling a story, which is what every writer should be doing.' If you aren't telling a story, you're a very dead writer indeed,' she says. 
With the main job of a writer being to entertain, Mollie is really an entertainer. 'I have this great love of not only the meaning of language but of the music of language,' she says. This love goes back to early childhood. 'I have told stories all my life. I had a school teacher who used to ask us what we would like to be when we grew up and, because my family always had dogs, and I was very good at controlling them, I said I wanted to work with dogs, and the teacher always said "Nonsense, Mollie dear, you will be a writer." So finally I thought that this woman must have something, since she was such a good teacher - and I decided when I was nine that I would be a writer.'

This childhood plan is described in her novel, A Sound of Chariots, which although is written in the third person is clearly autobiographical and gives a picture both of Mollie's motivation and her struggle towards its achievement.

Thoughts of her childhood brought thoughts of the time when her home was still a village with buttercup meadows and strawberry fields - sadly now covered with modern houses. 'I was once taken back to see it and I felt that somebody have lain dirty hands all over my childhood. I'll never go back,' she said. 'Never.'

To this day, Mollie has a lively friendship to children, which is reflected in the love she has for her writing. 'When we have visitors with children the adults always say, "If you go to visit Mollie, she'll spend more time for the children." They don't understand that children are much more interesting friends. I have heard all that the adults have to say before The children have something new.'

Read the text below and choose the correct word for each space. For each question, mark the correct letter A, $B, C$ or $D$ on your answer sheet. (There is only one possible answer.)

\section{Deep Sleep}

Deep sleep is important for everyone. The actual (6)..........of sleep you need depends (7)......your age. A young child (8)........to sleep ten to twelve hours, and a teenager about nine hours. Adults differ a lot in their sleeping (9)........ For most of them, seven to eight hours a night is $(10) \ldots \ldots \ldots$. but some sleep longer, while others manage with only four hours.

For a good night, having a comfortable (11)........to sleep is very important. Also, there should be (12)......... of fresh air in then room. A warm drink sometimes helps people to sleep, (13)......... it is not a good idea to drink coffee immediately before going to bed.

(14)...........you have to travel a very long distance, try to go to bed earlier than usual the day before the (15)......... This will help you to feel more rested when you arrive.

Part B. Specific English

Read the following text and choose the correct answer A, B, C or D for questions 18-23 on your answer sheet. (There is only one possible answer.)

\section{Pure and Applied Science}

Science is one of the greatest achievements of mankind. It was born in the gradual collection of knowledge about nature and has been developed by thousands of different scientists. Each scientist has added more knowledge to build on the knowledge of the past, and many scientists have developed theories, concepts and classifications in order to organize that knowledge. Thus, science is a cumulative body of organized knowledge about the natural world.

There are two main branches of science: pure and applied. The goal of pure science is to discover the relationships which exist among the objects and events in the universe. In trying to explain natural phenomena, the pure scientist develops theories, which are then tested by means of observation and experiment. When they are sufficiently validated, these theories become the principles of science. In other words, the goal of a pure scientist is to find out the laws of nature. What he learns may later turn out to be useful. But his goal is only knowledge, not usefulness. In biology, for instance, discovering the life cycle of a rare species of insect is an example of the work of pure science.

Applied science, on the other hand, has a different goal even though it uses the same method as pure science. The goal of applied science is to apply the laws of pure science to the practical problems of life. An applied scientist is interested in the usefulness of his knowledge. Determining which stage of an insect's life cycle causes the most damage to crops is an example of the work of an applied scientist of agriculture.

Read the passage below and answer the questions 24-30 on your answer sheet. (There is only one possible answer.)

\section{Cereals as a Main Food Source}

Cereals are the support of life to civilization. Around 70 percent of the world's harvested acreage of about thousand million hectares is devoted to growing cereals. They are the direct source of much additional food when converted to meat, milk, eggs, and other animal products.

The true cereals are all members of the grass family, the Gramineae. The fruit they produce is a grain called caryopsis, a type of fruit in which the ovary wall turns hard and durable, combining with the single seed. The major cereal crops are rice, wheat, maize, barley, rye, various millets, and a few other species.

There are a number of reasons why cereals have become man's main source of food. Most of them are yearly, or are at least adapted to cultivation as once-a-year, permitting facility in cropping. Like other grasses, cereals adapt well to a variety of soils, climates, and ways of controlling. They are also relatively efficient in gathering the sun's energy, changing it into usable food substance. In addition, they are generally strong and are not plagued by unusually large numbers of diseases and pests. Above all, the grain is a small package of stored energy, properly harvested, easily cleaned and managed, and suitably stored without need for artificial drying. 
Rice, wheat and corn are the world's three major cereals, all about equally important in terms of world production. Rice is the main source of substance for tropical populations; it is grown mostly on flood plains or where the land can be seasonally covered with still water. Wheat is mainly grown on lands that were naturally prairies, too harsh, cold, and windy for maize. Maize is a crop that grows best with ample warmth and moisture; it is widely used as a summer yearlong in areas where general farming is practiced.

\section{APPENDIX C POST-TEST}

Name:

Major: ................

Date:

Time: 35 Min

Part A. General English

Read the text and questions below. For each question, mark the correct letter A, B, C or D on your answer sheet. (There is only one possible answer.)

Ainsley Harriott

I have always been a bit of an entertainer and played a funny man. I was a part-time comedian for years, so I learned how to stand in front of audiences. It made me sure of myself. I like being liked and I love making everyone smile.

I've lived in London all my life and have just moved to a larger house with my wife Clare and our two children Jimmy and Madeleine. We spend a lot of time just singing and dancing around the house. I grew up with music because my dad is the pianist, Chester Harriott, who is still playing, by the way. My working day is divided between television and writing cook books, though TV takes most of my time. I spend about five days a fortnight working on the cooking programmes I appear in. I eat all sorts of things at home but I only buy quality food. When I'm cooking, I experiment with whatever in the fridge - it's good practice for my TV series.

I'm a football fan and enjoy going to matches, but I'm a home-loving person really. I don't like going to the pub but we do go out to eat about twice a month. There's nothing better than a night at home playing with the children. I rarely go to bed before midnight. Late evening is when fresh thoughts on cooking usually come to me, so I often write or plan my programme then. When I eventually get to bed, I have no trouble sleeping.

Part B. Specific English

Read the following text and choose the correct answer A, B, C or D for questions 16-30 on your answer sheet. (There is only one possible answer.)

Energy from the sun

Energy is defined as the ability or capacity to do work. Nearly all the energy used by man is derived from the sun, either directly or indirectly, in the form of heat rays or light rays.

Solar energy provides the light and warmth necessary for all animal and plant life upon the earth. The sun's light is essential in the process of photosynthesis, in which chlorophyll-bearing cells transform radiant energy from the sun into the chemical energy of carbohydrates. These carbohydrates serve as the basic substance in the food materials of plants and also the animals which consume plants.

The light and heat energy derived from fuel also comes indirectly from the sun. Coal was made by the pressure of rocks on vegetation which died millions of years ago. That vegetation grew with the aid of sunlight, from which carbohydrates were formed. Petroleum is another form of stored solar energy. Plants, together with the animals which fed on them, died millions of years ago, and their remains were pressed under the rocks in the earth. These dead animal and vegetable remains formed petroleum, from which gasoline and oil are now obtained.

Electrical energy is also obtained indirectly from solar energy; for example, it can be derived from the power of water falling down a mountainside. The sun's heat first causes water to evaporate from the surface of the earth. This water vapor rises, condenses on cooling, and falls upon mountains in the form of rain or snow, which later flows down the mountainsides in rivers. The electrical energy generated by windmills is also derived from the sun because all winds result from the uneven heating of different parts of the earth's surface by the sun.

Thus, it can be said that the sun is the source of nearly all our energy and that in the absence of the sun's heat and light, no life could exist on the earth.191

Read the passage below and answer the questions 21-25 on your answer sheet. (There is only one possible answer.)

\section{Plant diseases}

Crop plants are subject to many diseases that can reduce production and quality. The study of plant diseases-that is, the science of plant pathology- includes some insufficiency diseases caused by an imbalance in plant nutrients; most plant diseases are, however, caused by micro-organisms which live as parasites on plant hosts. A parasite which is the casual factor of a disease is called a pathogen.

The three main groups of microscopic plant pathogens are fungi, bacteria, and viruses.

Fungi. Fungi are the pathogens that cause the most damage to the greatest number of crops. Fungal infection spreads quickly from one host plant to another mainly by means of spores, which are the reproductive elements in fungi and which are comparable to the seeds in flowering plants. Vast numbers of tiny spores are produced by fungi and are spread by means of wind, water, and insects. Most parasitic fungi go directly into plant tissue to obtain their food. 
Common fungal diseases resulting in large crop losses are various types of blights on crops such as potatoes and various types of smuts and rusts on crops such as cereals.

Bacteria. Pathogenic bacteria enter plants only through natural openings, such as stomata, or through open wounds. Once inside the plant, they reproduce very rapidly. Insects are an important factor in the sending of bacterial disease, including various blights on fruit trees.

Viruses. Although many non-parasitic species of fungi and bacteria are known to exist, all known viruses are parasitic on plant or animal hosts. Viruses are commonly sent by insects, especially aphids; they usually enter plants through wounds caused by insect feeding or other means. Viral disease called mosaics which may infect potatoes or other crops, are characterized by a spotted pattern of yellow and green areas on plant leaves. Many viral diseases, however, are difficult to distinguish because they affect the plant in a general way by mild growing or yellowing and a reduced production.

\section{APPENDIX D KWL CHART}

Name:

Date:

Topic:

\begin{tabular}{|l|l|l|}
\hline What I Know & What I Want to Know & What I Learned \\
\hline & & \\
\hline
\end{tabular}

\section{REFERENCES}

[1] Hyland, K. (2007). Genre pedagogy: Language, litracy and L2 writing instruction. Journal of Second Language Writing, 16, pp.148-164. doi:10.1016/j.jslw.2007.07.005.

[2] Chandler, D. (1997). An introduction to genre theory. Retrieved June 8, 2005 fromhttp://www.aber.acuk/media/.

[3] Richards, C. \& Schmidt, R. (2002). Longman Dictionary of Language Teaching and Applied Linguistics. Malaysia: Pearson Education Limited.

[4] Hyon, S. (2001). Long-term effects of genre-based instruction: a follow-up study of an EAP reading course. ESP, 20, pp. 417438.

[5] Johns, A. M. (1997). Text, role and context: developing academic literacies. Retrieved October 14, 20011 fromhttp://books.google.com/.

[6] Carrell, P. L. (1985). Facilitating ESL reading by teaching text structure. TESOL Quarterly, 19, 727-752.

[7] Chen, H. (2008). Learning in new times: writing through the "eyes of genre". Retrieved May 4, 2008 fromhttp://ro.uow.edu.au/.

[8] Derewianka, B. (1990). Exploring How Text Works. Sydney: Primary English Teaching Association.

[9] Cometorich, L. (2009). Genre based approach. Paper presented at the Fifth Pan-Asian Conference on Language Teaching at FEELTA, Vladivostok, Russia. Retrieved June1, 2009 fromlanacometorich.blogspot.com/2009/06/genre-based-approach.html.

[10] Torok, S. \& Waugh, F. R (2006). Teaching English as a foreign language to grade 7 students in Thailand: Genre-based versus traditional method. Retrieved November 24, 2006 fromhttp://ro.ecu.edu.a/ceducom/109.

[11] Osman, H. (2004). Genre-based instruction for ESP. The English Teacher, 33, 13-29.

[12] Master, P. (2005). Research in English for specific purposes. In E. Hinkel, (Ed.), Handbook of research in second language teaching and learning (pp. 99-115). London: Lawrence Erlbaum Associates.

[13] Halliday, M.A.K. (1985). An introduction to functional grammar. London: Edward Arnold.

[14] Christie, F. (1999). Genre theory and ESL teaching: A systemic functional perspective. TESOLQUARERLY, 33, 759-763.

[15] Nunan, D. (1999). Second Language Teaching and Learning. Boston: Heinle \& Heinle.

[16] Badger, R. \& White, G. (2000). A process genre approach to teaching writing. ELT Journal, 54:2. Oxford. Oxford University Press.

[17] Miller, C. (1984). Genre as social action. Quarterly Journal of Speech, 70, pp151-167.

[18] Tuan, L. T. (2011). Teaching Writing through Genre-based Approach. Theory and Practice in Language Studies, 1 (11), 14711478.

[19] Farhady, H. (2006). English for the Students of Biology. Tehran: The Organization for Researching and Composing University Textbooks in the Humanities (SAMT).

[20] Haria, D. P. (2010). The Effects of Genre-Specific Reading Comprehension Strategy on Struggling Fifth Grade Students' Ability to Summarize and Analyze Argumentative Text. (Doctoral Dissertation, University of Delaware).

[21] Henry, A., \& Roseberry, R. L. (1998). An evaluation of a genre-based approach to the teaching of EAP/ ESP writing. TESOL Quarterly, 32, 147-156.

[22] Ribeiro, E. (2008). Effectiveness of the Genre-based Approach for Graduate Students. (Doctoral dissertation, Georgia State University).

Bahador Sadeghi, an assistant professor of Applied Linguistics holds a doctorate degree in TEFL from the University of Isfahan, Iran. He also holds three MAs in TEFL, English Translation and International Relations from Tehran Islamic Azad University, Isfahan University and Allameh Tabatabai University respectively. He has been lecturing different subjects in TEFL, Translation studies, General English and ESP at several universities in Iran for the last twenty years. He has both published and presented a 
number of articles in some international journals and conferences. He has translated twenty books from English to Persian. He is also a certified translator to the judiciary power in Iran and he has been, as a simultaneous interpreter, actively involved in many national and international seminars, sport events and tourism projects.

Mohammad Taghi Hassani, assistant professor in TEFL at Imam Hossein University, Tehran and Islamic Azad University, Takestan Branch, Iran. His research interests are EFL writing, psycholinguistics, phonetics, contrastive analysis, English for Specific Purposes, and language teaching methodology.

Mohammad R. Hemmati received his BA in 2002 and MA in 2012 in TEFL from the Department of English Language at Islamic Azad University of Takestan. He is currently teaching English at high schools and English language institutes in Kermanshah, Iran. 